\title{
How feasible is the life expectancy target in the Saudi Arabian vision for 2030 ?
}

\author{
Sulaiman Bah ${ }^{1}$ \\ ${ }^{1}$ College of Public Health, Imam Abdulrahman Bin Faisal University, Dammam, Saudi Arabia (Correspondence to: Sulaiman Bah: sbah@iau.edu.sa).
}

\begin{abstract}
Background: Over the period 2016-2030, Saudi Arabia seeks to increase life expectancy at birth by 6 years.

Aims: The main aim was to analyse the feasibility of this gain using the demographic literature.

Methods: The demographic literature on recorded high gains in life expectancy and the determinants of these gains were reviewed. The findings were examined considering the Saudi Arabian context.

Results: Explanations covered demographic and behavioural factors, inequalities, health care delivery system, public health provision, health-related policies and advancements in science and technology. However, the crucial factor is the country's position in the "cardiovascular revolution" (which combines smoking prevalence, obesity, lifestyle and related policies).

Conclusion: In countries where life expectancy is in the 70s, average yearly gains are less than 0.31 years, much lower that the Saudi Arabian target of 0.43 years. For Saudi Arabia, an average yearly gain of about half this is achievable provided the fundamental drivers of life expectancy are addressed.

Citation: Bah S. How feasible is the life expectancy target in the Saudi Arabian vision for 2030? East Mediterr Health J. 2018;24(4):401-404. https://doi. org/10.26719/2018.24.4.401

Received: 20/08/16; accepted: 07/03/17

Copyright @ ( World Health Organization (WHO) 2018. Some rights reserved. This work is available under the CC BY-NC-SA 3.0 IGO license (https:// creativecommons.org/licenses/by-nc-sa/3.0/igo).
\end{abstract}

\section{Introduction}

In April 2016, Saudi Arabia launched a very bold vision, Vision 2030, which outlined the future goals for the country, the justification for the goals and the structures that were being put in place for their achievement (1). Vision 2030 has been widely praised for its boldness and far-sightedness (2). While the primary goal is the diversification of the Saudi Arabian economy from being oil-based to being one not based on oil, the vision's ultimate goal is to make Saudi Arabia better in all spheres including, health and social well-being of the citizens.

Over the period 2016-2030, Saudi Arabia is aiming to increase life expectancy at birth by 6 years, from 74 years to 80 years, an average gain of 0.43 years per annum (1). Remarkable improvements have already been made in health and human development. Between 1980 and 2014 life expectancy at birth is estimated to have increased by 11.3 years. In 2014, the Human Development Index (HDI) for the country was 0.837. This puts Saudi Arabia in the category of those countries with "very high human development index" (for 2014, the average HDI for the Arab states was 0.686 while the average HDI of countries with "very high human development index" was 0.896) (3). There is, therefore, a basis for being forward-looking and targeting positive gains in life expectancy in the decades ahead.

The main aim of the paper is to assess the feasibility of the gain in life expectancy as outlined in the 2030 Vision document. The aim is achieved by first reviewing the demographic literature on recorded high gains in life expectancy and the determinants of these gains. This is followed by a discussion of the findings in the light of the Saudi Arabian context.

\section{Methods}

The demographic literature covering recorded high gains in life expectancy and the determinants of these gains is reviewed. This is then followed by an examination of the findings in light of the Saudi Arabian context.

\section{Results}

Review of the literature for achievement of high gains in life expectancy

Life expectancy at birth is a robust summary outcome measure that reflects a country's cumulative efforts (or lack thereof) in improving its population's health. In 2015, global life expectancy at birth ranged from 49.2 years in Swaziland to 83.7 years in Hong Kong (followed by Japan, with 83.3 years) (4). In general, low life expectancy at birth is usually associated with low levels of socioeconomic development, disproportionately high levels of infectious and parasitic diseases and deaths in infancy and childhood. High life expectancy at birth is usually associated with high levels of socioeconomic development and disproportionately high levels of noncommunicable diseases and death at an older age. Reduction in infant and child mortality leads to rapid gains in life expectancy at birth. Where life expectancy at birth is high, gains are achieved at a much slower pace. As an illustration, in Canada, which has a long series of good mortality data, the gain in life expectancy at birth over the period 1921-1951 was 11.3 years compared with the 
gain of 7.1 years between 1951 and 1981 and a gain of 6.2 years between 1981 and 2011 (5). During the period 19211951, the decline in infant and child deaths contributed 6.7 out of the 11.3 years gain in life expectancy. During the later period, 1981-2011, the decline in infant and child deaths only contributed 0.6 out of the 6.2 years gain in life expectancy (5). Reduction in deaths in the post-childhood years (5-74 years) contributed only 4.5 of the 11.3 years gain during $1921-1951$ but 4.2 of the 6.2 years gain during 1981-2011 (5).

A valid comparative analysis of gains in life expectancy presupposes the availability of an accurate set of life tables. International databases on life tables are maintained by different organisations, including the World Health Organization, United Nations Population Division, the World Bank and the Human Mortality Database. The first 3 of these aim at covering all countries, with varying levels of quality of mortality data. According to one United Nations report, "Many countries lack complete coverage of deaths through vital registration and, even where vital registration coverage is good, the reporting of cause-of-death on death certificates often suffers from inaccuracies. As a consequence, the mortality and cause of death estimates produced by the United Nations Population Division and the World Health Organization for many countries rely upon models that relate available measurements of mortality to what has been observed in other populations in the past" (6).

The Human Mortality Database however is more concerned with the quality of the mortality data than coverage of countries. In one study, out of the 22 countries whose life table data are included in the Human Mortality Database, the most accurate life tables with the longest historical series were selected from 10 countries, including Canada, France, Italy, Japan and the United States of America (USA) (7). From these data, between 1950 and 1980 the average annual gain in life expectancy at birth for females ranged from 0.182 years (England and Wales) to 0.595 years (Japan), and between 1980 and $2006 / 2007$ it ranged from 0.106 years (Netherlands) to 0.268 years (Japan). For males, the corresponding values ranged from 0.071 years (Netherlands) to 0.527 years (Japan) (1950-1980) and from 0.184 years (Denmark) to 0.306 years (Australia) (1980-2006/2007) (7). Of the 10 countries analysed over the 2 time periods, an average annual gain that equalled (or was greater than) the Saudi Arabian target of 0.43 years gain per year was only achieved by Japanese females over the earlier period, 1950-1980, when the life expectancy increased from 60.9 years to 78.95 years and by Japanese males over the same period, when the life expectancy increased from 57.58 years to 73.38 years. In the 1980 s, when life expectancy at birth in almost all of these countries was in the 70s, the average annual gains were all less than 0.31 years (7).

Review of the literature on the determinants of gains in life expectancy

When a country's life expectancy figures show gains (or losses) over time, researchers have used various approaches to explain the determinants of the change. Primarily, researchers have sought to explain the change using one or more of the following demographic dimensions: the contribution of different age groups, the contribution of male-female differences or the contribution of different causes of death. Explanations have also been sought through studying behaviour and its effects (e.g. smoking, accidents and obesity), inequalities (e.g. regional, economic or population groups), reasons related to the health care delivery system (e.g. access to care, quality of care), public health provision, health-related policies, advancements in science and technology and combinations of these factors. One theory that has attempted to capture many of these aspects is the reformulation of the health transition theory $(8,9)$. According to this, once a country has completed its classical epidemiology transition and its life expectancy is now in the 6os or 70s, the one crucial factor that would determine the trend in its life expectancy is its position in the "cardiovascular revolution" (which combines smoking prevalence, obesity, lifestyle and related policies). Countries that are disadvantaged by this revolution stand to gain less or lose life expectancy relative to others (hence diverge from the leading countries). Other countries that are not adversely affected by the revolution stand to continue improving life expectancy relative to others (hence converge with the leading countries). These findings were confirmed in a study in the USA on explaining the reasons for the divergence in life expectancy between the USA and other developed countries (7). The study concluded, "Smoking appears to be responsible for a good deal of the divergence in female life expectancy. Other factors, such as obesity, diet, exercise, and economic inequality, also have likely played a role in the current gap and divergence between the United States and other countries".

\section{Discussion}

Largely because of the behaviour-related problems of smoking, obesity and lifestyle, Saudi Arabia finds itself squarely in the "cardiovascular revolution" during the 2000s. In an article published in 2009, the median prevalence of smoking was given as $17.5 \%$ (10). According to a study published in 2014, "Of the 10735 participants evaluated, $28.7 \%$ were obese (body mass index $\geq 30 \mathrm{~kg} / \mathrm{m}^{2}$ ). Prevalence of obesity was higher among women (33.5\% vs 24.1\%). Among men, obesity was associated with marital status, diet, physical activity, diagnoses of diabetes and hypercholesterolemia, and hypertension. Among women, obesity was associated with marital status, education, history of chronic conditions, and hypertension" (11).

In addition, there is the serious problem of road traffic accidents. In 2010, there were 544179 accidents (20 for every 1000 population) which led to 7153 fatalities (1 for every 76 traffic accidents) (12).

It is these fundamental drivers of mortality that should be addressed if life expectancy at birth is to rise. However, unlike the earlier phase in the health transition when infant mortality could be reduced through various 
vertical programmes, there are no "quick fixes" in this stage. It has to be addressed through a combination of public health initiatives backed by very strong healthrelated legislation and implementation strategies. This, however, presupposes improvement in the data collection systems and the development of relevant indicators to measure and monitor the progress being made.

\section{Conclusion}

The Saudi Arabian vision for 2030 is an important milestone achievement that lays the foundation for the transformation of the Saudi Arabian economy and improving the population's health and social well-being. The higher the targets, the better, provided they are within achievable limits. From the literature, we can conclude that for a country whose life expectancy is in the 70s, the average yearly gain in life expectancy is less than 0.31 years, much lower that the Saudi Arabian yearly target of 0.43. For Saudi Arabia, an average yearly gain of about half this amount is achievable provided that the fundamental drivers of life expectancy are addressed.

Funding: None.

Competing interests: None declared.

\section{Dans quelle mesure la cible relative à l'espérance de vie du plan Vision 2030 de l'Arabie saoudite est-elle réalisable?}

\section{Résumé}

Contexte : L’Arabie saoudite prévoit une augmentation de l'espérance de vie à la naissance de 6 ans sur la période 20162030.

Objectifs : L'objectif principal était d'analyser la faisabilité de ce gain en utilisant la littérature démographique.

Méthodes : La littérature démographique a recensé les gains élevés en termes d'espérance de vie, et les déterminants de ces gains ont été évalués. Les résultats sont examinés via le prisme du contexte saoudien.

Résultats : Les explications qui en découlent couvraient les facteurs démographiques et comportementaux, les inégalités, le système de prestations de soins de santé, la fourniture de services de santé publique, les politiques liées à la santé et les avancées dans les domaines de la science et de la technologie. Cependant, le facteur crucial est la position du pays au sein de la «révolution cardio-vasculaire » (qui combine une réduction de la prévalence du tabagisme et de l'obésité, des changements dans le mode de vie et des politiques y afférentes).

Conclusion : Dans les pays où l'espérance de vie se situe entre 70 et 79 ans, les gains annuels moyens sont de moins de 0,31 année, soit beaucoup plus bas que la cible de 0,43 année fixée par l'Arabie saoudite. Pour l'Arabie saoudite, un gain annuel moyen équivalant à environ la moitié de ces chiffres est réalisable, si les facteurs fondamentaux contribuant à l'augmentation de l'espérance de vie sont réunis.

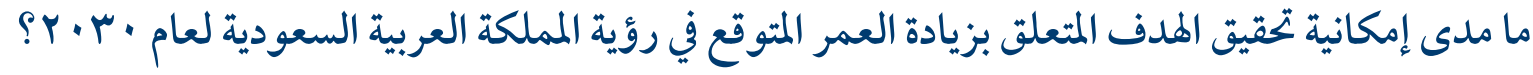

$$
\begin{aligned}
& \text { سليمان باه } \\
& \text { الخلاصة }
\end{aligned}
$$

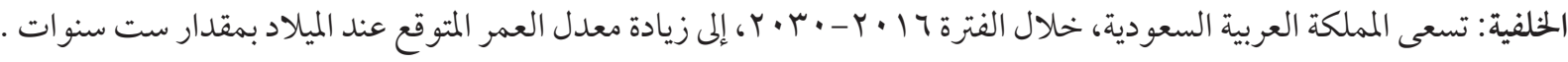

$$
\begin{aligned}
& \text { الأهداف: تمثل الهدف الأساسي في تحليل إمكانية تحقيق هذا المكسب باستخدام الدراسات السكانية السابقة. } \\
& \text { طرق البحث: سجلت الدراسات السكانية السابقة مكاسب عالية تتعلق بزيادة معدل العمر المتوقع، واستعرضت الدراسة الحالية محددات هذه } \\
& \text { المكاسب كما تم استعراض النتائج بمراعاة سياق المملكة العربية السعودية. }
\end{aligned}
$$

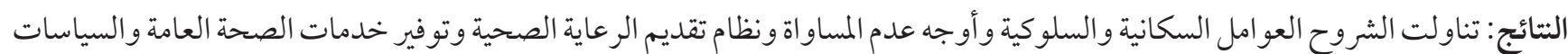

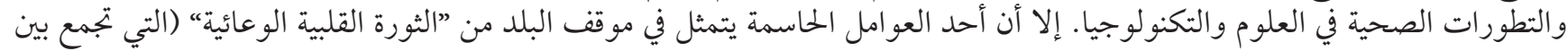

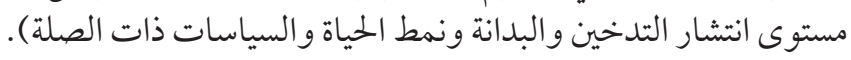

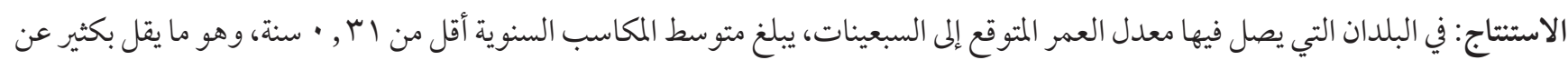

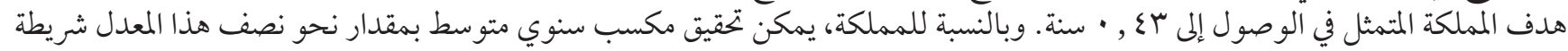

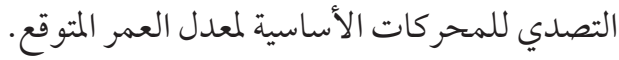




\section{References}

1. Vision 2030: Kingdom of Saudi Arabia. Riyadh: National Transformation Program; 2016 (http://www.vision2030.gov.sa/en/ntp, accessed 15 January 2018).

2. World reacts to Saudi Arabia's 'Vision 2030'. Al Arabiya English [Online] 26 April 2016 (http://english.alarabiya.net/en/News/ middle-east/2016/04/26/Global-reactions-to-Saudi-Vision-2030-announcement.html, accessed 2 January 2018).

3. Human development report 2015: work for human development. New York: United Nations Development Programme; 2015 (http://hdr.undp.org/en/content/human-development-report-2015-work-human-development, accessed 2 January 2018).

4. World population prospects: the 2015 revision, key findings and advance tables, 2015 revision. New York: United Nations, Department of Economic and Social Affairs, Population Division; 2015 (ESA/P/WP.241) (https://esa.un.org/unpd/wpp/ publications/files/key_findings_wpp_2015.pdf, accessed 2 January 2018).

5. Decady Y, Greenberg L. Ninety years of change in life expectancy. Ottawa: Statistics Canada; 2014 (http://www.statcan.gc.ca/ pub/82-624-x/2014001/article/14009-eng.pdf, accessed 2 January 2018).

6. Changing levels and trends in mortality: the role of patterns of death by cause. New York: United Nations, Department of Economic and Social Affairs, Population Division; 2012 (http://www.un.org/en/development/desa/population/publications/ mortality/changingLevelsAndTrends.shtml, 2 January 2018).

7. National Research Council. Explaining divergent levels. Washington DC: The National Academies Press; 2011 (http://www.nap. edu/catalog/13089/explaining-divergent-levels-of-longevity-in-high-income-countries, 2 January 2018).

8. Vallin J, Meslé F. Convergences and divergences in mortality. A new approach to health transition. Demographic Research. 2004;Special Collection 2(Article 2):11-44 (https://www.demographic-research.org/special/2/2/s2-2.pdf, accessed 2 January 2018).

9. Meslé F, Vallin J. Historical trends in mortality. In: International handbook of adult mortality. Crimmins EM, Rogers RG, eds. New York: Springer; 2011.

10. Bassiony M. Smoking in Saudi Arabia. Saudi Med J. 2009; 30(7):876-81. PMID:19617999

11. Memish Z, El Bcheraoui C, Tuffaha M, Robinson M, Daoud F, Jaber S, et al. Obesity and associated factors: Kingdom of Saudi Arabia, 2013. Prev Chronic Dis. 2014;11:E174. PMID:25299980.

12. Ratrout NT, Chowdhury S, Gazder U, Masiur Rahman S. Characterization of crash-prone drivers in Saudi Arabia - a multivariate analysis. Case Studies on Transport Policy. 2017;5(1):(134-42 (https://ac.els-cdn.com/S2213624X16300748/1s2.o-S2213624X16300748-main.pdf?_tid=01403180-fabo-11e7-924b-00000aabofo2\&acdnat=1516102130_ co8b971636dboagdcaa2b475f9bdcbda, accessed 16 January 2018). 